\title{
Customer Relationship Management a Strategic Tool: An empirical Study with reference to four wheeler automobile industry in Nagpur City
}

\author{
Dr. Gajanan G. Babde \\ Assistant Professor \\ Nutan Adarsh Arts, Commerce \& M. H. Wegad Sceince College, Umred, Nagpur.
}

\section{Introduction:}

The entire focal point of Customer Relationship Marketing is to build positive experiences with customers to keep them satisfied and happy. Customer Relationship Marketing refers to the principles, practices and guidelines that an organization follows when interacting with its customers. The whole relationship encompasses direct interactions with customers through sales and services. To enhance the customers overall experience Customer Relationship Management plays a vital role.

Customer Relationship Management is the branch of management that centers on elaborating the term and putting its associated principles to work for achieving the strategic objectives. CRM allows an organization to forge new relationships, and better manage existing relationships, with all the stake holders like customers, dealers, distributors, suppliers and others. According to Roger Joseph Baran and Daniel P. Strunk in the book; Principles of Customer Relationship Management; CRM is about effectively managing the customers with the great care to satisfy the customers.

Customer Relationship Management is the concept of a planning and a structure to manage the relationship with individual customers. A CRM tool allows a business to manage customer relationships in a structured and organized way by using software that is normally hosted inhouse or on demand, in the cloud. Customer Relationship Management is a system for managing a companyees interactions with current and future customers. It involves use of technology to organize, automate and synchronize sales, marketing, customer service activities, and technical support.

Customer Relationship Management provides leverage in the following areas like:

1) Managing customer enquiries and leads.

2) Managing communication with prospects and current customers.

3) Market Segmentation.

4) Managing promotions and marketing campaigns.

5) Managing account of loyal customers.

The easiest way of making customers feel more valued and part of two-way relationship is to continually make them feel valued for their business and loyalty. To create value and increase 
satisfaction, loyalty organization needs to plan variety of actions and activities. CRM strategy is important as it gives direction to the activity of business in an organization. The focal point of Customer Relationship Management is to increase the companyees proximity with the consumers for further cementing the relationship between both of them. Customer relationship is useful in keeping the track records of existing customers and also useful in acquiring new customers. Process can be completed with strategic planning.

\section{Need for CRM in the organisation:}

The ultimate purpose of CRM, like any organizational initiative, is to increase profit. In the case of CRM accomplishment is mainly by providing a better service to your customers. CRM not only improves the service to customers though; a good CRM capability will also reduce costs, wastage, and complaints. Effective CRM also reduces staff stress, because attrition - a major cause of stress - reduces as services and relationships improve. CRM enables prospect of lines of communications with customers and gives straight and steady market reaction to your products, services and performance, far better than any market survey. Good CRM also helps to nurture the business: customers stay with you longer; customer churn rates reduce; referrals to new customer ${ }^{\text {re }} \mathrm{s}$ increase from increasing numbers of satisfied customers; demand reduces on fire-fighting and trouble-shooting staff, and overall the organization's service flows and teams work more efficiently and more happily.

1) The significant need of CRM is discussed briefly as follows:

2) Need of Customers

3) For generating a customer focused CRM solution

4) Customers' Expectations $\square$

5) Managing Customers $\square$ Building relationships

\section{Customer Relationship Management Strategies:}

Achieving the long-term value of Customer Relationship Management requires a strategy involving the whole business and should be approached at an enterprise level. A CRM strategy is composed of separable and individually analysed activity which includes service initiatives, value propositions, special benefits or privilege created for the customers. The strategic perspective of CRM is all about strategies for the success of Customer Relationship Management. The CRM strategy and each activity must be aligned with the companyee mission, culture and values.

\section{Automobile Industry in India:}

The automobile industry in India is one of the largest industries and key sector of the economy. India is the second largest producer and manufacturer of two-wheelers in the world. Indian two-wheelers in the world have got spectacular growth in last few years. The Indian automotive industry began its journey from 1991 with the government"s de-licensing of the sector and subsequent opening up for 100 per cent FDI through automatic route. Due to which large globe companies have set up their facilities in India taking the production of 
vehicle in leaps and bounce. Two-wheelers dominate the Indian market; more than 75 per cent of the vehicles sold are two-wheelers.

The changes in design, models and make of the two-wheelers with the help of advancement of technology have enabled the Indian automotive industry to compete globally in the cut thought competition. The automobile sector in India is witnessing double digit growth in past few years accounting for much of the phenomenal growth in two-wheeler industry. The Indian four-wheeler industry, comprise of Hatchback, Sedan, SUV, etc. Fourwheelers are the most popular mode of transportation in Nagpur (India), due to its affordability and convenience. India is seeing the penetration of four-wheelers increasing at a rapid pace driven by the rise in the household incomes, reducing trend in excise duties and hitherto easy availability of four-wheeler finance.

The growth of Indian middle class, with increasing purchasing power, along with strong macro-economic fundamentals has boosted the business of auto manufacturers in Nagpur. With the rising urbanization and vehicle growth particularly in the mid-sized cities like Nagpur, India, it is imperative for local governments and other stakeholders to explore and implement relevant two-wheeler management strategies Growing population due to attractive employment, educational facilities and better life style attracts many aspirants to settle in Nagpur city, as result of this and non-availability or irregularity of mass transport is driving people towards two-wheelers, easy loans and financing have boosted the use of fourwheeler. In Nagpur, comfort, convenience and enjoyment are the top reasons shared by the riders as the unreliability of public transportation. After realizing the growth drivers of auto four-wheelers in Nagpur city, dealers play an important role to boost the business by taking care of customers by making them satisfy and provide as per the requirement the products and the services. To develop strong and healthy relationship with the present customers and invite the new customer"s companies and dealers need to practice the Customer Relationship Management.

\section{Literature Review:}

According to Anshari, M., Almunawar, M. N., Lim, S. A., \& Al-Mudimigh, A. (2019), the emergence of big data brings a new wave of Customer Relationship Management $(\mathrm{CRM})$ ees strategies in supporting personalization and customization of sales, services and customer services. CRM needs big data for better customers experiences especially personalization and customization of services. Big data is a popular term used to describe data that is volume, velocity, variety, veracity, and value of data both structured and unstructured. Big data requires new tools and techniques to capture, store and analyse it and is used to improve decision making for enhancing customer management. The aim of the research is to examine big data for $\mathrm{CRM}^{\text {ee }}$ s scenario. The method of collection of data for this study was literature review and thematic analysis from recent studies. The study reveals that CRM with big data has enabled business to become more aggressive in term of marketing strategy like push notification through smartphone to their potential target audiences. 
Badwan, J. J., Al Shobaki, M. J., Abu-Naser, S. S., \& Abu Amuna, Y. M. (2017) conducted a study on „Adopting technology for customer relationship management in higher educational institutions ${ }^{\text {ee }}$. The aim of this paper is to evaluate the critical success factors and investigate the benefits that might be gained once implementing Electronic Customer Relationship Management at HEI from students' perspective. The study conducted at Al Quds Open University in Palestine and data collected from (398) students through a questionnaire which consists of four variables. Some statistical tools were used for analyzing the data and testing the hypotheses, including Spearman correlation coefficient for Validity reliability correlation using Cronbach's alpha, Frequency, and Descriptive analysis. The overall findings of the current study show that all the features were important for student and it was critical success factors, at the same time, websites were providing all the features discussed by the theory whereas students showed their willingness to use those features if provided. It is also discovered that implementing Electronic Customer Relationship Management can cause customer satisfaction, loyalty, retention and high service quality as students pointed to be a customer. Research limitations: The survey findings were based on QOU students in Palestine. UAE and KSA branches are not included in the study.

Aldaihani, F. M. F., \& Ali, N. A. B. (2018) conducted a study on „Impact of Electronic Customer Relationship Management on customers satisfaction of the five stars hotels in Kuwaite. The study aims to investigate the impact of electronic customer relationship management on customers satisfaction of the five stars hotels in Kuwait, four dimensions of the Electronic Customer Relationship Management namely (Website design, ability to search on Website, Privacy and security, and Delivery time), the customers satisfaction was the dependent variable. The study population consisted of all of the customers of the five stars hotels in Kuwait (15) hotels. A convenience sampling was taken from customers staying in five stars hotels in Kuwait from different nationalities. To collect data from the study sample, a questionnaire was built based on the previous studies. To achieve the study objective, and test the hypotheses a statistical program SPSS was used. Results of the study indicated that Website design, Search ability on Website, Privacy and security, and Delivery time had a significant and positive impact on Customer satisfaction. Based on the study results, the researchers recommend the managers and decision makers of the five stars hotels in Kuwait to develop mechanisms to enhance the ease of use of the website of the five stars hotels in Kuwait and avoid complexity, and to focus on training their employees in communication and problem-solving skills Rahimi,

\section{Research Methodology:}

Research is a combination of experience and reasoning, which is regarded as the most successful tactic to find the fact. Research is search of knowledge through objectives based on implicit questions to collect the explicit answer. According to Clifford Woody, research comprises defining and redefining problems, formulating hypothesis or suggested solutions, collecting, organizing and evaluating data making deductions and reaching conclusions and further testing the conclusion whether they fit into formulating hypothesis. 
For gaining more insights about the intentions, research frame work aims to describe the methodology to give information about the study.

\section{Objectives of the study:}

The objectives of the proposed study are:

1. To examine the relationship between Customer Relationship Management practice and its components.

2. To identify the role of employees ${ }^{e e}$ experience, skill sets and knowledge in achieving CRM goals in auto four-wheeler industry in Nagpur.

3. To examine the factors affecting satisfaction level of customers in auto four-wheeler industry in Nagpur.

4. To identify the customers preferred features while buying four-wheelers.

5. To understand the perception of the customers towards the respective dealers in Nagpur city.

\section{References:}

1. Anshari, M., Almunawar, M. N., Lim, S. A., \& Al-Mudimigh, A. (2019). Customer relationship management and big data enabled: Personalization \& customization of services. Applied Computing and Informatics, 15(2), 94-101.

2. Badwan, J. J., Al Shobaki, M. J., Abu-Naser, S. S., \& Abu Amuna, Y. M. (2017). Adopting technology for customer relationship management in higher educational institutions.

3. Rahimi, R., Köseoglu, M. A., Ersoy, A. B., \& Okumus, F. (2017). Customer relationship management research in tourism and hospitality: a state-of-the-art. Tourism Review.

4. Paliouras, K., \& Siakas, K. V. (2017). Social Customer Relationship Management. International Journal of Entrepreneurial Knowledge,

5. Simanjuntak, M., Putri, N. E., Yuliati, L. N., \& Sabri, M. F. (2020). Enhancing customer retention using customer relationship management approach in car loan bussiness. Cogent Business \& Management, 7(1), 1738200.

6. Edlund, P., \& Holmner Härgestam, A. (2020). Customer relationship management and automated technologies: a qualitative study on chatbots" capacity to create customer engagement. 8. BEKELE, H. (2020). 